Sadagat Aliyeva, Head of the Department of Culturology Azerbaijan State University of Culture and Arts, Candidate of Cultural Sciences, Associate Professor, Honored Worker of Culture, Azerbaijan res0980@mail.ru https://orcid.org/0000-0002-7062-341X

\title{
THE MORAL CRISIS AND SALVATION OF WOMEN
}

The article explores the similarity between the Japanese formula about the ideal of women «a good wife and a wise mother» and the Nazi slogan for the ladies «Kinder, Küche, Kirche» (i.e. children, kitchen, church). Further, the author shows that the life of the American woman of the fifties described by Betty Friedan in its nature does not differ much from the above formulations. Even under these conditions, the weaker sex demonstrated resistance to a monotonous life. The theory of female archetypes by Jean Shinoda Bolen showed that female types are different from each other. Modern Azerbaijani science, taking this into account, should be armed with new theories in order to find the key to the psychology of various types of women in the country.

Key words: moral crisis, female psychology, the West, feminism, gender, the East, tradition.

Садагат Алиева, заведующая кафедрой культурологии, Азербайджанский государственный университет культуры и искусств, кандидат культурологии, доцент, Заслуженный работник культуры, Азербайджан

\section{МОРАЛЬНЫЙ КРИЗИС И СПАСЕНИЕ ЖЕНЩИН}

Исследованы сходство между японской формулой об идеале женщин "хорошая жена и мудрая мать» и нацистским лозунгом - «Kinder, Küche, Kirche» (дети, кухня, церковь). Рассмотрено жизнь американской женщины, описанной Бэтти Фридан в 50-х гг. Даже в этих условиях слабый пол демонстрировал сопротивление к однообразной жизни. Охарактеризована женская психология. Теория женских архетипов Джин Болен показала, настолько женские типы различны. Современная азербайджанская наука, учитывая это, должна вооружаться новыми теориями, чтобы найти ключ к психологии разных типов женщин страны.

Ключевые слова: моральный кризис, женская психология, Запад, феминизм, гендер, Восток, традиция.

Садагат Алієва, завідувач кафедри культурології, Азербайджанський державний університет культури і мистецтв, кандидат культурології, доцент, Заслужений працівник культури, Азербайджан

\section{МОРАЛЬНА КРИЗА І ПОРЯТУНОК ЖІНОК}

Актуальність. Акцентується увага на гендерній проблемі як одній з актуальних соціальних і культурних проблем сучасності; досліджено питання розвитку культурних процесів в наш час, а також розробки механізмів гендерних проблем у суспільстві. Сьогодні дискримінація за ознакою статі, заборони і забобони стосовно жінок набули широкого поширення в наукових, соціальних дискусіях і в засобах масової інформації. 
Мета статті - звернути увагу на паралелі та розбіжності між поглядами на статус жінки в східній та західній культурах як на частину актуальної гендерної проблеми.

Методологія. У статті використано прийоми міжкультурного порівняння, а саме елементи наративного та компаративістського підходів.

Результати. Виявлено подібність японської формули про ідеал жінки «хороша дружина і мудра мати» до нацистського гасла «Kinder, Küche, Kirche» («дитина, кухня і церква»). Життя американської жінки 1950-х рр. по суті не відрізняється від наведених вище формулювань. Забезпечення гендерної рівності $€$ актуальним у багатьох країнах світу. Набуття проблемою серйозного характеру перешкоджає культурному і соціальному прогресу. Це призводить до соціальної несправедливості. Чимало європейських учених під час дослідження гендерних проблем у теоретичних концепціях намагаються проаналізувати їхню культурну сутність. Проблемам жінок в азербайджанській культурі не приділено достатньої уваги, порівняно з тими, які були досягнуті у світовій практиці і особливо в західному мисленні в останні два століття. Така ж ситуація існує у всіх країнах Північної і Південного Кавказу, Близького і Далекого Сходу і, можливо, у багатьох країнах Латинської Америки.

Новизна. Уперше в культурологічній практиці проаналізовано концепції шаріату і патріархальної жінки порівняно з поглядами на статус жінки у західному світі та в колишньому Радянському Союзі. Показано, що прогресивна культурно-освітня політика в Азербайджані та деяких країнах Центральної Азії сприяє поступовій емансипації жінки Сходу.

Практичне значення. Матеріали та висновки статті можуть бути корисними при подальшому крос-культурному вивченні ґендерних проблем, а також при розробці практичних рекомендацій до розробки культурної політики та складання навчальних посібників з питань ґендерної проблематики.

Ключові слова: моральна криза, жіноча психологія, Захід, фемінізм, гендер, Схід, традиція.

Problem statement. The attitude to women in Azerbaijani culture is very deplorable in comparison with that in the world practice, especially in Western thinking. Some scholars may say that this is the case not only in our culture. The same situation exists in the whole of North and South Caucasus, the Near and Far East, and possibly in many Latin American countries. When it comes to Latin American countries, the lack of ideas on women is compensated by the achievements of Spanish culture. Perhaps, Turkey is playing such a compensatory factor in Azerbaijan (with the advent of the Internet and the fall of the Iron Curtain, Turkish science has begun to play the role of additional information, intellectual source for Azerbaijanis).

Previous research. In comparison with the West, Turkey's research into the feminism, for example, had a lower impact than Russia's success. However, Russia`s success cannot be overestimated because the West acts as a powerful compensating factor for it. Women's psychology, women's 
sociology, and even women-oriented philosophical thoughts are imported from Russia or the West. In the European and American spiritual world, women are represented not only in bright, often controversial scales. In this world, women have a very dramatic and emotionally fertile character literature, cinema and theatre. This is the case in practice. In the theory, women are the source or target of the most innovative ideas due to psychoanalysis, analytical psychology, behaviourism, feminist, postmodernist research, and gender science.

Everyday consciousness sees a woman who fits in a stereotype of ordinary life, but there is a serious necessity for gender research. Let's explain in a parallel. In 1890, that is Meiji era, the Japanese government shaped the idea of «good wife and wise mother» in relation to women and set up gender policies on that basis. This ideology was the Japanese version of Victorian ideology. Thus, in the Japanese reality, a conglomerate of Confucius science and westernism was formed. As a result the woman world was identified as house and kitchen (Modern Japanese Society, 2004).

The aim of the article is to explore similarity between the Eastern and Western ideal of women, with an emphasis on Azerbaijani reality.

The main text. Another analogy of this conglomerate was in Azerbaijan. True, we had no Confucius philosophical tradition. However, the conglomerate was derived from Islam, the notion of Sharia and patriarchal women concept and the result was the restriction of the world of feminism to the home and children. It should be noted that though the Soviet ideology made unprecedented parliamentary quota and revolutionary steps towards women's education, there was a very important cultural community in Azerbaijan, Central Asia, where women still lived in the world of non-emancipationism.

Of course, neither in the Japanese society nor in Azerbaijan, in a restricted world, the woman who took the burden of «a good wife and a wise mother» did not seem a dull, narrow-minded creature. As these societies regarded those women, who undertook to be a good wife and mother, mostly with admiration, such women were encouraged to remain on the path they had chosen. The society acted with respect and sympathized with "true" women and thus they received a moral reward for their hard life. Sati ritual which is a sign of virtue of the widow in Hinduism is not common in Azerbaijan (Interesting facts about Indians). It is known that, according to this ritual, the Indian woman had to demonstrate high morality by voluntarily agreeing to be burned with her husband. Even though this ritual is unfamiliar to Muslims, even in Azerbaijan, if a widow devotes herself to her children and does not marry another man, this fact is admired by most men, although we should also mention a paradox. Historically, two or three marriages of women in Azerbaijan are not an ordinary event. The widow's marriages were 
widely practiced by our grand-grandmothers, and one of the reasons was the simple ritual of the marriage and divorce among the Muslims.

Rigorous attitude to women, that is, the demand to live a restricted life with many prohibitions, was not only characteristic of the Eastern world. A similar situation also manifested itself in puritan morals, Victorian morality. Betty Friedan has shown that in the twentieth century, under the influence of Freudism in the West, women were inspired by the fact that their basic value and virtue were femininity. They should appreciate and develop their femininity. Accordingly, researchers welcomed those women whose main aim was to marry and raise children and thus to fulfil their femininity. As a result of the environment created by women's ideals, at the end of the '50s, the age of women in America who got married fell to 20.14 million girls were married at the age of 17 . In the mid-50's, $60 \%$ of girls studying at the college left education because they were married. Therefore, at the end of those years, the birth rate was higher in the USA that even in India.

Being a wife and living in a suburban house turned out to be the ideal of American women. Betty Friedan says that after the war, men were talking about politics, work, and water pollution for 15 years when women talked about children, marriages, and so on. The woman felt ashamed when she got tired of the femininity of during 50-60s. It seemed to her that something was wrong. After all, other women seemed to be happy in their lives. Such women would never have thought that other women could experience similar problems. For a long time, American women did not know what the problem was, sometimes they said, «I live as if I do not exist». Betty Friedan emphasizes one point in this regard: «I know that many women conceal their internal dissatisfaction with their lives because they do not fit in the image of the «true and good woman» created by experts. However, it is possible to summarize the thoughts and dissatisfaction of most women like that: I'm either a mother of my children or a priest, wife of a police officer, but I'm never myself».

It is very interesting that the situation that troubled American women became aphorism in the rhymed slogan of the Nazis: Kinder, Küche, Kirche that is children, kitchen, church.

Betty Friedan develops her idea of thinking of the American woman's moral crisis and ways of salvation, and writes that the inner voice of women now says, «I need something other than husband and children». Friedan later adds: «... and this voice should be heard!».

TVs, advertisements, women's magazines, films, novels, articles, family experts, psychoanalysts in America have long ago formulated such a female image that she is a well-behaved, calm girl at school age, then a student in love with a boy, then a housewife who prepares her children for school, sees 
her husband off, and welcomes him back from work. This image shaped the lives of women and told them what is to be desired (Betty Friedan). It is not difficult to see that this image, which was promoted in the United States by that time, is still common in such countries as Azerbaijan, Turkey and Uzbekistan. There is only one difference. In the countries we listed, this image is modified. Thereby, they cancel the part «a student girl in love with a boy». Because while in these cultures the possibility of a student girl's love for a boy is acceptable, there is no tolerant approach to the legitimacy of such an act. They prefer to keep quiet about it.

Looking at the life of American women, the difference in the East lies in the fact that in modern Azerbaijan and Turkey women are now interested in the great world events and politics. Not all, but most are interested.

Betty Friedan then raises a very serious question: why did it so happen that women confine themselves within the family by abandoning the world around them?

In the answer she recalls one occasion. In 1942, Farnham and Lundberg published a book entitled «Modern Women - the Lost Sex». Its main idea is that business and higher education masculinises a woman, that is make her a male creature (Men's fears of the woman). This is a great deal of damage to the family and motherhood.

According to Friedan, only gradually women realized that many American women have the same problem, mental poverty, created by a rigorously restricted life (Fromm, 1993, p. 23). In 1960, the New York Times, News week, and SBC began to say that the American woman is not happy, although the reason for this misfortune she wrongly sees in workers who make a poor repair of household appliances.

The main idea of Betty Friedan is that those who considered women's development as the main virtue had, in fact, put women into a narrow world in America. As a result, there was a problem of mental illness in women who wanted to realize themselves in a broad socio-cultural world. This problem became apparent from women's depression and the fact that women did not feel satisfied, complete.

As we have seen, the restriction of the virtuous woman's ideal to the kitchen world as a good wife is characteristic not only of the Oriental tradition based on the moral values of the Confucian culture or the basis of Sharia. This was also the case in the typologically different puritan American culture. The narrow and restricted world of women causes them to appear in narrow and limited psychology, so in such cultures there is such idea that the psychology of the woman is so much the same that there is no need to set different approaches to studying them. 
In the world where women's rights are widely protected and respected, especially in the society where women have the right to benefit from economic resources, there are many women with different psychological carriers instead of the same type of female psychology. Of course, human psychology is that the most repressive, «robotic» societies have psychological differences in such individuals. Under the Fascist regime, the Sanguine people were still different from the Phlegmatic ones. There were differences in extrovert personality types from introvert ones. It also refers to women. Even in very strict patriarchal societies psychological differences manifest themselves. Simply, the rigid standards of morality lead to the fact that in typical socio-political and cultural situations, some girls behave differently, even though at present the brides are wearing the same social mask and playing the same social role. However, psychological peculiarities sometimes evolve deep differences. If psychological differences in societies are able to severely restrict morality, then what do psychological differences between women in liberal societies lead to?!

The societies restricting women's virtues to the conditions of a good wife and mother ideal excludes their chances to become sevicemen, scientists, actresses, social workers, politicians, etc. In fact, this means that hundreds of situations of the social and psychological life of women are beyond their reach. If a woman is not allowed to leave for a foreign country without her men relative (her son, husband, brother, etc.), or if a woman in Saudi Arabia always travels under the patronage of her brother or father, then she is insured against unexpected surprises. This woman's life is, of course, different from the lives of girls and women who have been sent to Africa for helping refugees, who are reporting from war areas. Thus, unlike societies with strong moral and cultural control, women in free societies live a very risky, adventurous life. As literature and cinema in the West describe these women's lives, a lot of extraordinary women appear. In such case, women manifest themselves in such psychological colourfulness that the scientists and journalists who are thinking about them are in a very difficult situation because the available theoretical apparatus does not allow this new situation to be seriously investigated. In such cases it is clear that there are gaps in psychological theories regarding women. At present, the state of Azerbaijani science concerning women is in such a «crying» condition. However, the majority of women in the social-political arena without any restrictions demonstrate that these non-aesthetic artistic works and scientific theories are ridiculous.

It was the case in the West formerly for some period. However, after Betty Friedan wrote about the dull life of the Latin American woman, the situation of the women has changed since 60 s. She went to the width of the social life from the narrow world of house and housekeeping. As in the case 
of men, career, politics, art, and social activity drove her life out of mental poverty. It turned out that women, as well as men, are carriers of various psychologies. The sameness that appear when a woman's character is restricted to the idea of «good wife and wise mother", is the actually visible, external side. Inside the women there is also a potential for diversity. The need to analyze this created a need for new challenging and original feminine theories. Jean Shinoda Bolen's book, «Goddesses in Every Woman», was one of the first to answer this call. Her theory was the creative transformation of Carl Jung's analytic psychology. Therefore, the «application» does not mean that the archetypes of the Austrian scientist are «shadow», «mask» «anima», «animus», «wise old man.» His follower Bushlyar exposed these archetypes to creative transformation and changed these into "stone", "water", "air" and similar archetypes (Niyazi Mehdi, 2007, p. 66-68). Bolen formed a full and detailed theory using the archetype terms in relation to Greek goddesses. For this reason, the main types of women were identified as Greek goddesses. Bolen wrote that while working as a psychotherapist after listening to hundreds of women, she came to the conclusion that every woman wanted to be a leading person in her life. Thus, there is a goddess hidden in every woman. Previously, women did not know how powerful the cultural stereotypes were. And now they still do not know what majestic force is hidden inside.

Bolen speaks of archetypes based on the psychological type of women to make clear that gigantic power. For example, it can be seen that a fullfledged life imagination and ideal for one woman type may seem totally meaningless to the other under the influence of another archetype. In some women, several archetypes can live side by side. It is important for women to know under what influence of the archetype which is symbolized by the goddess of understanding they are. Women who identify themselves with female virgins are like «lonely wolves», and others lose their sense of love for them. The goddesses such as Artemis, Aphrodite, and Hestia often affect women like that. However, thinking about archetypes can also be achieved with positive results. For example, a suitable female type can boost the Artemis archetype. It is known that this goddess was the goddess of hunt in Greek mythology. She symbolized independence, living in nature. The girl who found herself loyal to Artemis's archetype would no longer see the abnormality of her character as she did not see the meaning of her life in loving a boy. She would know that there are thousands of girls who with Artemis archetype, and there are also male types that are attracted by such girls. If we look at the history of Azerbaijan, outlaw Gulsum, known by the name of Suleiman, as was in the psychology of the archetypal symbolized by the hunt goddess, after shooting those who oppressed his father, fled to the woods, wore male clothes and joined the men. She then killed Jackal Salim 
as she could not stand his plundering the poor and gathered her troops around her (Zaur Oliyev).

By the way, Jean Shinoda showed that wisdom and art goddess Athene and home goddess Hestia were similar to virgins in Greek mythology. In addition to their functional differences, they had similarities that they did not need a male world and did not need male support in solving their problems. True, girls who are in the archetype of virgin goddesses can get married, but the difference is that they tend to take control of their husbands and take on all their family initiatives. However, women in Athenes archetype have a certain psychological peculiarity. They love to be at male councils, not because they need men, but because they love the goals and purposes of men. They take part at such meetings and show leadership qualities. Bolen shows that in America, Claire Louis was a vivid emblem of Athenes archetype. She was, on the one hand, a woman famous for her beauty. On the other hand, she was known as a playwright and was also a member of the Congress. She was also an ambassador to Italy. Claire Louise succeeded in man's lifetime and won admiration of men. Some thought that she was even cold-blooded, intriguing because of her courage in front of dangers. The Athenes was the goddess of art in particular, the goddess of weaving. In women who had migrated from America to Europe, according to Bolen, Athenes archetype was very strong. They sewed all clothes of their husbands, family and were wise advisors to their husbands (Jean Shinoda Bolen).

Conclusion. As can be seen, Jean Shinoda Bolen offered a new key to emancipation psychology of American women who came from the housewives. Since then, women's psychology has become a serious subject in Western science, and at the end of the 20th century, in the early years of the 21 st century, it has given birth to a new discipline - gender studies. In the creation of this science, of course, the role of research on women was promising. Of course, from the theory of archetypes, it can be seen that there are many women who the see meaning of their life in their home and family. However, from this theory it seems that other types of women have the right to live according to their nature. Women can also find their happiness as men in different activities, different ideals and goals. Therefore, it is not right to unite all women into a framework of good wife and a wise mother. We do not say that the women's freedom of diversity brings them happiness. There are both happy and unhappy women among those who have chosen any path and have any impact of the archetypes on themselves. Happiness and unhappiness are not guaranteed to any woman or any man. Simply the emancipation of women has an advantage that the psychological diversity that is not burdened with the diversity of men creates a favourable environment for high 
art, science and culture. Knowing this, Azerbaijani researchers should seriously study the psychology the Azerbaijani woman.

\section{References}

Modern Japanese Society (2004). Josef Kreiner, Ulrich Möhwald and Hans Dieter Ölschleger (Ed.). (Part 5, Vol. 9). BRILL, p.183 [In English].

Interesting facts about Indians. Retrieved from http://indonet.ru/Statya/ Interesnye-fakty-ob-indiankah [In Russian].

Betty Friedan. The mystery of femininity. Retrieved from https://www.e-reading.club/bookreader.php/1019773/Fridan_-_Zagadka_zhenstvennosti.html [In Russian].

Men's fears of the woman. Retrieved from http://mjusli.ru/psihologija/ lyubovnye-otnosheniya/muzhskie-straxi-pered-zhenshhinoj [In Russian].

Fromm, E. (1993). Psychoanalysis and ethics. Moscow: Respublika, p. 23. [In Russian].

Niyazi Mehdi (2007). Archeology of art, architecture of art. p. 66-68 72-79. [In Azrbaijanian].

Zaur Oliyev. Stalin's rescue, the Armenians' nightmare: men's dressed fugitive

Gulsum. Retrieved from http://publika.az/news/qirmizi/114219.html [In Azerbaijanian].

Bolen, J. Sh. Goddesses in every woman, The new psychology of women. Archetypes of the goddesses. Retrieved from http://www.psylib.org.ua/ books/bolen01/index.htm [In Russian].

Надійшла до редколегіi 19.03.2018 p. 